\title{
The Effect of Organizational Justice on Employees' Affective Commitment
}

\section{The Mediating Role of Job Satisfaction}

\author{
Taghrid S. Suifan ${ }^{1}$ \\ ${ }^{1}$ Department of Business Management, The University of Jordan, Jordan \\ Correspondence: Taghrid S. Suifan, Department of Business Management, The University of Jordan, Amman \\ 11942 Jordan. Tel: 962-6535-5000. E-mail: t.suifan@ju.edu.jo
}

Received: December 5, 2018

Accepted: February 17, 2019

Online Published: January 3, 2019

doi:10.5539/mas.v13n2p42

URL: https://doi.org/10.5539/mas.v13n2p42

\begin{abstract}
This study aims to examine the indirect relationship between organizational justice and employees' affective organizational commitment via the mediating effect of job satisfaction. In the research design, all three dimensions of organizational justice - distributional, procedural, and interactional - were considered. A questionnaire was distributed to 361 employees of pharmaceutical companies in Jordan, with a response rate of $93 \%$. Data from the questionnaires were then analyzed and the study's hypotheses were tested with structural equation modeling using Amos 20. The results confirmed that job satisfaction plays a mediating role between organizational justice and affective commitment. This accords with the findings of similar studies in developed countries, emphasizing the vital role of organizational justice in shaping employees' behaviors and attitudes. This study is unique in investigating a concept that has been rarely explored in developing countries. It will help improve the scarcity of such research, especially in the Middle East. The study also urges that future research further tests this model in additional developing contexts to enable more generalized conclusions.
\end{abstract}

Keywords: distributional justice, employees' affective commitment, interactional justice, job satisfaction, Jordan, pharmaceutical industry, procedural justice

\section{Introduction}

While prior studies have decisively concluded that employees' perceptions of fairness in the workplace significantly affect their attitudes and behaviors towards their organization (Colquitt, Conlon, Wesson, Porter, \& $\mathrm{Ng}$, 2001; Latham \& Pinder, 2005), recent years have witnessed rekindled interest in the important concept of organizational justice and its significant effect on various employee attitudes, such as job satisfaction, turnover intention, and organizational commitment (Choi, Moon, Ko, \& Kim, 2014). However, as employees' perceptions of justice do not directly generate initiative behaviors, affective commitments to the organization must be created in advance (López-Cabarcos, Pinho, \& Rodríguez, 2016). For example, Gumus, Hamarat, Colak, and Duran (2012) demonstrated that high levels of organizational justice are positively related to job satisfaction, affective commitment, and trust. In particular, organizational justice has been proven to boost employees' job satisfaction levels and thereby positively influencing their affective commitment, which is necessary to have in order for individuals to perform their best (Zainalipour, Fini, \& Mirkamali, 2010). In fact, Moon, Hur, Ko, Kim, and Yoon (2014) asserted, based on research findings, that employees who perceive that justice in their workplace is high are more affectively committed to their organization.

These studies have highlighted the extreme importance of organizational justice in shaping employees' behaviors and attitudes. Just treatment in the workplace, along with the creation of a fair atmosphere, inspires employees to demonstrate desirable behaviors toward their co-workers, managers, and the entire organization (Mohammad et al., 2016). Accordingly, it is essential for organizations to focus on implementing organizational justice and to view it as a priority for cultivating satisfaction and affective commitment among employees who are, in turn, able to achieve organizational goals and objectives. Employee satisfaction, retention, and commitment are critical issues for organizations in the current era of knowledge workers (Eisenberger \& Rezaei, 2016). Since several studies have confirmed the positive effect of organizational justice delivery on job satisfaction and affective organizational commitment (Aküzüm, 2014; Imran, Majeed, \& Ayub, 2015; Kofi, Asiamah, \& Mireku, 2016), organizational 
justice implementation is, thus, fundamental in maximizing employees' work outcomes.

Since every organization's ultimate goal is to achieve sustainable performance and growth, and virtually every organization seeks to maximize employee productivity, it is important to note that a primary determinant of an employee's productivity is their affective commitment to their organization. Therefore, by implication, to achieve optimum employee productivity, organizations should both optimize and reap the benefits of individual employees' commitment (Kofi et al., 2016).

Although the relationship between organizational justice and work outcomes has been established in Western literature, this relationship has yet to be investigated in developing Eastern countries (Y. Hao, J. Hao, \& Wang, 2016). In this respect, organizational justice needs to be further investigated in a non-Western context as a potential predictor for employees' job satisfaction levels and, in turn, as a clear antecedent of employees' affective organizational commitment. Imran et al. (2015) found a positive relationship between organizational justice and employees' job satisfaction levels. Elamin (2012) revealed that organizational justice plays a significant role in influencing Saudi employees' level of job satisfaction and commitment while Suliman and Al Kathairi (2012) show that organizational justice (procedural and interactional) is positively and significantly correlated with affective commitment, continuance commitment, and job performance. Al-Zu'bi (2010) found a positive association between organizational justice and job satisfaction amongst employees in electrical industrial companies in Jordan. Accordingly, the present study aims to explore the indirect relationship between justice perceptions and employees' affective commitment through the mediating effect of job satisfaction. The study was conducted in the non-Western developing country of Jordan, focusing particularly on the context of pharmaceutical manufacturing companies. This study proposes a research framework that will broaden existing knowledge of the consequences of organizational justice perceptions. The results could provide scholars and practitioners with suggestions and recommendations on how job satisfaction and affective commitment could be supported in pharmaceutical manufacturing companies.

\section{Literature Review}

\subsection{Organizational Justice}

Organizational justice can be traced back to the 1980s when Greenberg (1987) is said to have formally introduced the term (Park, Song, \& Lim, 2016). Since then, organizational justice has emerged as one of the most important concepts in management research (Rai, 2015). It involves the fair treatment of employees within the organization (Skarlicki \& Kulik, 2004), and it is an important prerequisite for the effective functioning of an organization (Morin et al., 2011).

Various dimensions of organizational justice have been introduced in the organizational justice literature. Among one of the most acknowledged approaches is the three-factor model that separates organizational justice into three dimensions: distributive, procedural, and interactional justice (Choi et al., 2014; Park et al., 2016). While earlier research classified organizational justice into five factors/dimensions comprised of distributive, procedural, interactional, interpersonal, and informational justice (Folger \& Cropanzano, 1998; Greenberg, 1990b), modern scholars have mostly aggregated the last two factors (interpersonal and informational justice) under the umbrella of one dimension: interactional justice.

The first dimension, distributive justice, refers to an employee's perception of fairness regarding output distribution amongst their peers (Greenberg, 1990a; Colquitt et al., 2001). Here, output comprises both monetary and nonmonetary items (such as salary, benefits, promotions, etc.) that employees receive in exchange for their invested input in the workplace (Kofi et al., 2016). Employees draw comparisons between their own output/input ratio and those of their peers. They evaluate whether they are being fairly compensated for the amount of effort they invest, using their peers' compensation package as their benchmark. If the ratio is the same for all peers, then it can be said that distributional justice has been achieved within that organization (Ohana \& Meyer, 2016).

The second dimension, procedural justice, concerns employees' perception of the methods, procedures, and processes used by the organization in distributing monetary and/or non-monetary outcomes amongst its employees (Folger \& Cropanzano, 1998). In other words, procedural justice refers to the perceived fairness of the decisionmaking process by which outcomes are distributed (Wang, Liao, Xia, \& Chang, 2010). It also encourages employees to achieve their personal objectives, satisfies the specific need for interpersonal attachments (Chênevert, Jourdain, Cole \& Banville, 2013), and relates to the fairness of the decision-making processes that affect employees (López-Cabarcos et al., 2016)

The third and final dimension, interactional justice, concerns employees' perceptions of their treatment during the enactment of organizational procedures (Bies, 2001; Bies \& Moag, 1986). As the definition suggests, interactional 
justice is comprised of two aspects: interpersonal justice and informational justice. Interpersonal justice concerns the interpersonal treatment of employees within the organization, specifically whether they are treated properly, with dignity, politeness, and respect. Conversely, informational justice relates to the quality of information made available to employees in terms of providing adequate explanations and rationales for decisions made by superiors (Cheung, 2013; Lam, Loi, \& Leong, 2013).

\subsection{Affective Commitment}

Organizational commitment is mostly defined in the literature as a measure of an employee's psychological attachment to their organization (Lambert, 2003; Kofi et al., 2016). There seems to be consensus among researchers to view organizational commitment as a multi-dimensional construct that is mainly comprised of three dimensions: affective, normative, and continuance commitment (Meyer \& Allen, 1991). Several studies have confirmed that there is a positive link between the various forms of organizational justice and affective commitment (e.g., Chou, Seng-cho, Jiang, \& Klein, 2013; Marzucco, Marique, Stinglhamber, De Roeck, \& Hansez, 2014; Ohana, 2014; López-Cabarcos, et al., 2016).

The first dimension, affective commitment, describes an employee's emotional attachment towards their organization, which governs their involvement and level of commitment within that organization (Mensah, Akuoko, \& Ellis, 2016). It indicates an employee's emotional belonging to, identification with, and engagement within an organization (Allen \& Meyer, 1990). It is usually characterized by the employee's willingness to work extra hours, a sense of identification and attachment with the organization, and the absence of both turnover and turnover intent (Kofi et al., 2016). The second dimension, normative commitment, is based on an employee's sense of obligation toward their organization (Akanbi \& Ofoegbu, 2013). While the first two dimensions principally relate to the psychological/emotional aspect, the third dimension, continuance commitment, does not. Instead, it refers to an employee's commitment to the organization based on evaluating the costs associated with leaving (Meyer \& Allen, 1991).

Affective commitment is the dimension most likely to have a strong relationship with workplace outcomes since employees impart greater effort when they possess high levels of attachment, identification, and internalization (Giri \& Kumar, 2013). Consequently, it is considered the most widely studied dimension of the three (Esfahani, Ghasemi, \& Tabrizi, 2014). Additionally, in most studies, of all three dimensions, affective commitment yields the most reliable results (López-Cabarcos et al., 2014). It has been demonstrated that normative and continuance commitments have persistent, unstable reliabilities in cross-cultural contexts (Liao, Hu, \& Chung, 2009). Thus, several recent studies focused solely on affective commitment as a measure of the overall organizational commitment construct (e.g., Saha \& Kumar, 2017). Therefore, this research focuses on organizational justice as a key factor affecting employees' affective commitment.

\subsection{Job Satisfaction}

Job satisfaction is a widely popular construct in the literature (Saha \& Kumar, 2017). A widely accepted definition of job satisfaction is that of Locke (1976, p. 1304): "a pleasurable or positive emotional state resulting from the appraisal of one's job or job experiences." A more recent definition describes job satisfaction as the difference between the amount of valued outcome that employees receive and the amount of that outcome they feel they ought to receive (Halepota \& Shah, 2011).

It is interesting to note that job satisfaction encompasses both an emotional and attitudinal aspect. It involves how an employee feels towards their job (emotional aspect), and whether that employee will form a positive or negative evaluative judgment about their job situation (attitudinal aspect) (Barakat, Isabella, Boaventura, \& Mazzon, 2016). It is, therefore, a very important construct that is of extreme value to organizations. This is due to numerous studies highlighting job satisfaction as a potential determinant of many workplace outcomes, such as organizational commitment, turnover, absenteeism, performance, etc. (Goh, Elliott, \& Quon, 2012). Furthermore, the importance of job satisfaction stems from the fact that it can easily be influenced by an organization's actions, with its primary antecedents within the scope of management's influence (Saha \& Kumar, 2017). Consequently, an organization's actions can elicit either positive or negative emotions amongst its employees (Barakat, Isabella, Boaventura, \& Mazzon, 2016). This gives organizations leverage to influence employee attitudes, such as job satisfaction and organizational commitment.

\section{Theoretical Framework}

\subsection{Organizational Justice and Affective Commitment}

Numerous researchers have empirically studied the two constructs of organizational justice and organizational commitment, and the studies have generally confirmed a positive relationship between them (Moon et al., 2014; 
Imran et al., 2015; Kofi et al., 2016). More specifically, several studies have focused particularly on examining the relationship between organizational justice and affective commitment. Conclusions from those studies reveal that when an organization's employees perceive that high levels of organizational justice are present, they manifest higher levels of affective organizational commitment (Rego \& Cunha, 2008; Colquitt et al., 2013; Moon et al., 2014; Ohana \& Meyer, 2016).

The explanation for this positive correlation could be attributed to theories of social exchange and reciprocity. When employees are treated fairly and perceive the presence of justice in their workplace, they interpret this as the organization demonstrating concern for them; thus, they will want to reciprocate in the spirit of social exchange by voluntarily becoming more affectively committed (Ohana \& Meyer, 2016).

Based on the above argument, organizations that treat employees in a fair and respectful manner are better able to nurture positive attitudes, such as affective commitment; hence, the following hypothesis is proposed:

\section{$H_{I}$ : There is a positive and significant effect of organizational justice on employees' affective commitment.}

\subsection{Organizational Justice and Job Satisfaction}

According to Abekah-Nkrumah and Atinga (2013), all three dimensions of organizational justice have a theoretically significant influence on an employee's job satisfaction. In fact, prior literature reveals a significant relationship between organizational justice and job satisfaction (e.g., Abekah-Nkrumah \& Atinga, 2013; Crow, Lee, \& Joo, 2012). While justice in the workplace leads to feelings of contentment and satisfaction with one's job, the converse is that lower levels of organizational justice stimulate employee dissatisfaction, resentment, and even bitterness towards the organization (Rae \& Subramaniam, 2008).

Based on the above discussion, job satisfaction is proposed as an outcome of organizational justice:

\section{$H_{2}$ : There is a positive and significant effect of organizational justice on job satisfaction.}

\subsection{The Mediating Role of Job Satisfaction}

Among the three organizational commitment dimensions, it has been found that affective commitment is the most correlated with workplace outcomes, especially job satisfaction (Meyer, Stanley, Herscovitch, \& Topolnytsky, 2002). Furthermore, several studies have uncovered that the level of affective commitment varies based on an employee's job satisfaction level (Jernigan, Beggs, \& Kohut, 2002). While most studies have regarded job satisfaction as an independent variable, it is actually more favorable to consider job satisfaction as a mediating variable (Lok \& Crawford, 2001; Jernigan et al., 2002). Organizational support given to employees improves positive behaviors and attitudes like affective and normative commitment (Riggle, Edmondson, \& Hansen, 2009); on the other hand, perceived organizational support has either an insignificant effect (Randall, Cropanzano, Bormann, \& Birjulin, 1999) or a negative effect (LaMastro, 2008).

In addition, previous research has demonstrated that high levels of organizational justice are positively associated with job satisfaction and affective commitment (Gumus et al., 2012). If employees perceive that their efforts at work are fairly reciprocated, they will demonstrate affective commitment to the organization (He \& Brown, 2013). Eisenberger et al. (1986) found that when people feel that an organization acts fairly, they interpret such fair actions as signals indicating that the organization cares about and values them.

Based on the above literature, the following two hypotheses are proposed:

\section{$H_{3}$ : There is a positive and significant effect of job satisfaction on employees' affective commitment.}

$H_{4}$ : There is a positive and significant mediation effect of job satisfaction between organizational justice and employees' affective commitment.

\section{Methodology}

Pharmaceutical manufacturing companies in Jordan were selected for the study. These are knowledge-intensive businesses that form part of the service sector. They are distinguished from other kinds of firms in that they claim the following unique qualities: they have qualified local human resources, and they produce qualified products and/or services (Dahiyat, 2015). According to the Jordanian Association of Pharmaceutical Manufacturers, as of March 2017, there were 14 such companies in Jordan with a combined total of 5,484 employees, all of which were included in this research's subject population. Using stratified random sampling based on the number of employees in each company, a recommended research sample size of 361 was derived from this population. Some employees were discouraged from participating in this research by their organizations' internal policies, which decreased the total number of participating employees. Of the 361 distributed questionnaires, 337 (93\%) were completely answered. Of the 337 respondents, 194 (57.6\%) were male and 143 (42.4\%) were female. (86.3\%) were 30 to 40 
years old, $65.6 \%$ held a bachelor's degree, and (93.5\%) were employed at a non-managerial level. The unit of analysis is head of department and supervisors and non-managerial employees.

\subsection{Measures}

As previously stated, distributive justice relates to employees' perceptions about the fairness of outcomes, including payment, promotion, rewards, etc. This construct will be measured using a five-item scale originally established by Niehoff and Moorman (1993), measured on a five-point Likert-type scale.

Procedural justice, which focuses on the perceived fairness of the processes by which outcomes are distributed amongst employees, will be measured using Niehoff and Moorman's (1993) six-item scale, measured on a fivepoint Likert-type scale.

The final dimension of organizational justice - interactional justice - entails treating employees with interpersonal and informational dignity, respect, honesty, and candidness. It will be measured using Niehoff and Moorman's (1993) six-item scale, also measured on a five-point Likert-type scale.

Defined as the extent of an employee's attachment to, sense of unity with, and interest in the future of their organization, the dependent variable, affective commitment, was measured using the six-item measure developed by Allen and Meyer (1990, 1996), Meyer and Allen (1991), and Mowday, Porter, and Steers (1982), measured on a five-point Likert-type scale.

Finally, for the mediating variable, job satisfaction is defined as an employee's psychological disposition towards their job. It will be measured through six items developed by Lee (2002), using a five-point Likert-type scale.

\subsection{Validity and Reliability}

Construct validity was assessed through exploratory and confirmatory factor analyses (EFA and CFA, respectively), beginning with the EFA methods of principal component analysis and promax rotation. All the question items were entered simultaneously and the pattern matrix revealed five distinct factors, as had initially been expected. Some items loaded onto two factors or showed factor loadings less than 0.40 and were thus deleted. Moreover, eigenvalues for all the resulted factors were greater than 1.0. Cronbach's $\alpha$ coefficient indicated high reliability of the measurement scales, with $\alpha>0.70$ implying satisfactory internal consistency (Hair, Black, Babin \& Anderson, 2010).

Next, based on the EFA results, CFA was performed using Amos 20. Additional question items were deleted to improve model fit indices. The final model fit indices, using first order constructs, fitted the data reasonably well $\left(\mathrm{X}^{2}=307.378\right.$; d.f. $=142 ; \mathrm{X}^{2} /$ d.f. $=2.16$; comparative fit index $(\mathrm{CFI})=0.952$; goodness-of-fit index $(\mathrm{GFI})=0.912$; non-normed fit index $(\mathrm{NNFI})=0.942$; normed-fit index $(\mathrm{NFI})=0.915$; root mean square error of approximation $($ RMSEA $)=0.059$; and root mean square residual $(R M R)=0.042)$. The normed chi-square of 2.16 was below the maximum value of 3.0 (Bollen, 1989). The CFI, GFI, NFI, and NNFI were each greater than the suggested minimum value of 0.90, while the RMSEA and RMR both indicated acceptable values (Hu \& Bentler, 1999). These indices indicated a sufficient level of unidimensionality and convergent validity. Moreover, the standardized coefficients for all the items were greater than twice their standard errors, indicating additional support for convergent validity (Anderson \& Gerbing, 1988). Furthermore, all the factor loadings were greater than 0.50 , while average variance extracted (AVE) values for all the measurement scales exceeded 0.50 , providing additional evidence of convergent validity (Fornell \& Larcker, 1981). The composite reliability for all the scales exceeded 0.70 , indicating a satisfactory level of reliability (Fornell \& Larcker, 1981). Table 1 shows the standardized factor loadings of EFA and CFA, Cronbach's $\alpha$ values, and composite reliability for the measurement scales. The final model fit indices using second-order constructs (organizational justice, job satisfaction, and affective commitment) also fitted the data reasonably well $\left(\mathrm{X}^{2}=331.633\right.$; d.f. $=146 ; \mathrm{X}^{2} /$ d.f. $=2.27$; $\mathrm{CFI}=0.946$; $\mathrm{GFI}=0.906 ; \mathrm{NNFI}=$ $0.937 ; \mathrm{NFI}=0.908 ; \mathrm{RMSEA}=0.062$ and $\mathrm{RMR}=0.050$ ).

Table 1. Reliability and Validity of the Constructs

\begin{tabular}{|c|c|c|c|c|c|c|c|}
\hline Construct & Item number & Mean & S.D. & $\begin{array}{l}\text { Loadings } \\
\text { EFA }\end{array}$ & $\begin{array}{l}\text { Loadings } \\
\text { CFA }\end{array}$ & $\begin{array}{l}\text { Cronbach's } \alpha \\
\text { (reliability) }\end{array}$ & Composite reliability \\
\hline \multirow{5}{*}{ IJ } & & 3.75 & 0.782 & & & & \\
\hline & IJ1 & & & 0.93 & 0.762 & 0.878 & 0.882 \\
\hline & IJ2 & & & 0.858 & 0.809 & & \\
\hline & IJ3 & & & 0.883 & 0.878 & & \\
\hline & IJ5 & & & 0.728 & 0.775 & & \\
\hline
\end{tabular}




\begin{tabular}{|c|c|c|c|c|c|c|c|}
\hline \multirow[t]{5}{*}{ DJ } & & 3.19 & 0.91 & & & & \\
\hline & DJ1 & & & 0.798 & 0.857 & 0.837 & 0.855 \\
\hline & DJ2 & & & 0.797 & 0.596 & & \\
\hline & DJ3 & & & 0.943 & 0.821 & & \\
\hline & DJ5 & & & 0.74 & 0.796 & & \\
\hline \multirow[t]{4}{*}{ PJ } & & 3.24 & 0.842 & & & & \\
\hline & $\mathrm{PJ} 2$ & & & 0.819 & 0.808 & 0.872 & 0.873 \\
\hline & PJ3 & & & 0.783 & 0.818 & & \\
\hline & PJ5 & & & 0.863 & 0.792 & & \\
\hline \multirow[t]{4}{*}{ JS } & & 4.04 & 0.648 & & & & \\
\hline & JS3 & & & 0.69 & 0.76 & 0.747 & 0.751 \\
\hline & JS5 & & & 0.897 & 0.729 & & \\
\hline & JS6 & & & 0.84 & 0.631 & & \\
\hline \multirow[t]{5}{*}{$\mathrm{AC}$} & & 3.46 & 0.906 & & & & \\
\hline & $\mathrm{AC} 2$ & & & 0.872 & 0.757 & 0.848 & 0.85 \\
\hline & AC3 & & & 0.802 & 0.807 & & \\
\hline & AC5 & & & 0.882 & 0.797 & & \\
\hline & AC6 & & & 0.661 & 0.698 & & \\
\hline \multirow[t]{4}{*}{ Justice $^{a}$} & & 3.39 & 0.698 & & & & \\
\hline & $\mathrm{IJ}^{\mathrm{b}}$ & & & 0.823 & 0.702 & 0.764 & 0.815 \\
\hline & $\mathrm{DJ}^{\mathrm{b}}$ & & & 0.801 & 0.77 & & \\
\hline & $\mathrm{PJ}^{\mathrm{b}}$ & & & 0.853 & 0.839 & & \\
\hline
\end{tabular}

Notes. ${ }^{\text {a: }}$ Second-order factors; ${ }^{\text {b: }}$ Second-order indicators. IJ: interactional justice, DJ: distributive justice, PJ: procedural justice, JS: job satisfaction, AC: affective commitment.

Discriminant validity was evaluated by ensuring that the square root of each AVE value was greater than the absolute correlation value between that scale and other scales. All the measurement scales met this criterion, indicating strong support for discriminant validity (Fornell \& Larcker, 1981), as shown in Table 2. Additionally, the AVE value for each measurement scale exceeded maximum shared squared variance (MSV) and average shared squared variance (ASV) values, providing further support for discriminant validity (Hair et al., 2010).

Table 2. AVE, MSV, ASV, and Correlation Matrix of Second-Order Constructs

\begin{tabular}{lllllll}
\hline Construct & AVE & MSV & ASV & 1 & 2 & 3 \\
\hline 1. Justice & 0.597 & 0.557 & 0.424 & 0.772 & & \\
2.JS & 0.502 & 0.373 & 0.332 & 0.54 & 0.708 & \\
3. AC & 0.587 & 0.557 & 0.465 & 0.746 & 0.611 & 0.766
\end{tabular}

Notes. ${ }^{* *} \mathrm{p}<0.001$; Square root of AVE is displayed on the diagonal. JS: job satisfaction, AC: affective commitment.

\section{Results}

The research hypotheses were tested using structural equation modeling (SEM) with maximum likelihood estimation using Amos 20. SEM allows simultaneous testing of direct and indirect effects. The results showed that the effect of organizational justice on affective commitment is positive and significant $(\beta=0.587, p<0.001)$, thus supporting $H 1$. The effect of organizational justice on job satisfaction was also positive and significant $(\beta=0.540$, $\mathrm{p}<0.001$ ), thus supporting $H 2$. For the direct effect of job satisfaction on affective commitment, the results revealed a positive and significant effect $(\beta=0.294, \mathrm{p}<0.001)$; therefore, $H 3$ was also supported.

The mediation effects were tested using the bootstrapping method (Shrout \& Bolger, 2002), which is more accurate than the method proposed by Baron and Kenny (1986) (MacKinnon, 2008; Mallinckrodt, Abraham, Wei, \& Russell, 2006). The main advantages of the bootstrapping re-sampling approach are that it is appropriate for both large and small samples, and this method does not require a normal distribution assumption for the indirect effect (Hayes, 2009). We selected 1,000 bootstrap samples with $99 \%$ bias-corrected confidence intervals (Hayes, 2013). To accept or reject our hypothesis regarding the indirect effect $(\mathrm{H} 4)$, the lower and upper bounds of confidence intervals needed be checked. If these two bounds include zero, then the alternate hypothesis is rejected, since this means 
that the indirect effect is zero with $99 \%$ confidence level. Conversely, if the two bounds do not include zero, then the alternate hypothesis is accepted.

The results showed that job satisfaction positively and significantly fully mediated the relationship between organizational commitment and affective commitment (the confidence intervals are between 0.062 and $0.270, \mathrm{p}<$ 0.01 ); thus, $H 4$ was also supported. Figure 1 illustrates the direct and indirect effects, and Table 3 provides a summary of each tested hypothesis.

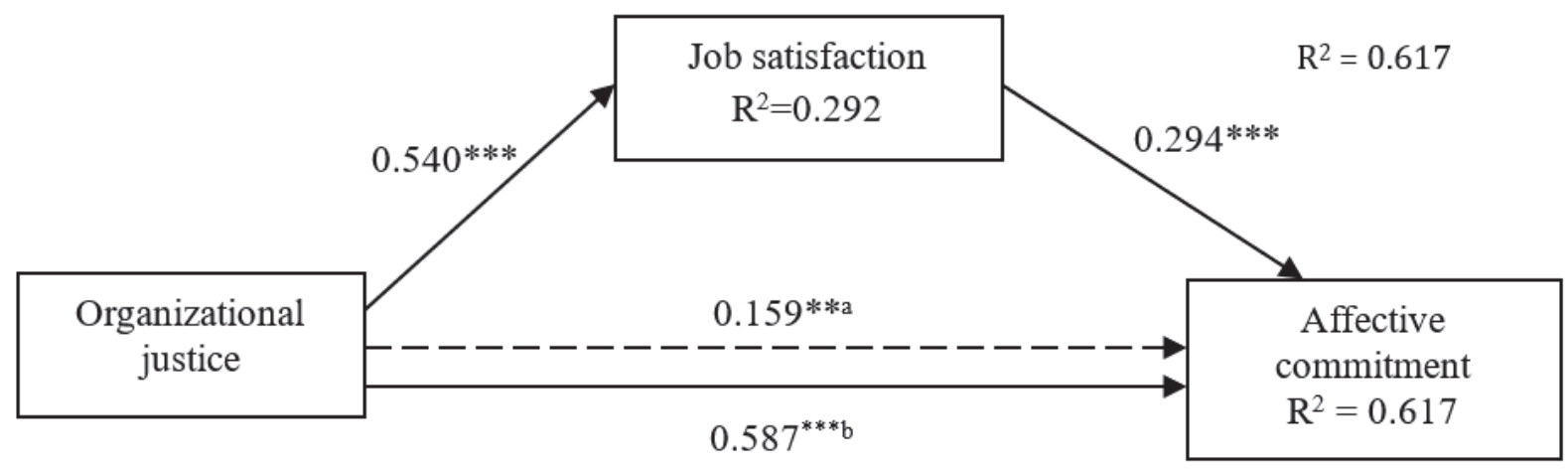

Figure 1. Hypothesized Model Illustrating Direct and Indirect Relationships

Notes. ${ }^{* * *}: \mathrm{p}<0.001 ;{ }^{* *} \mathrm{p}<0.01 ;{ }^{\mathrm{a}}$ : indirect effect; ${ }^{\mathrm{b}}$ : direct effect.

Table 3. Summary of Results

\begin{tabular}{llll}
\hline Hypothesis & Path & Coefficient & Result \\
\hline H1 & JUS $\rightarrow$ AC & $0.587^{* * *}$ & Supported \\
H2 & JUS $\rightarrow$ JS & $0.540^{* * *}$ & Supported \\
H3 & JS $\rightarrow$ AC & $0.294^{* * *}$ & Supported \\
H4 & JUS $\rightarrow$ JS $\rightarrow$ AC & $0.159^{* *}$ (indirect effect) & Supported \\
\hline
\end{tabular}

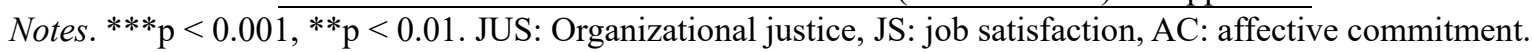

\section{Discussion}

The study's results reveal that job satisfaction indeed plays a significant mediating role between organizational justice and affective commitment. These findings elucidate organizational justice as the antecedent for the whole reaction chain, which accords with previous studies (e.g., Rai, 2015) that have depicted justice as one of the most important concepts in management research. This study also confirms the findings of former studies (e.g., Gumus et al., 2012; Imran et al., 2015; Kofi et al., 2016) that have demonstrated a positive relationship between organizational justice, job satisfaction, and affective commitment: the higher the perceptions of organizational justice in the workplace, the greater employees' satisfaction with their jobs and, therefore, the more committed they will feel toward their organization. Other recent studies merely examined two of the three types of organization justice while also revealing a positive relationship. For example, Moon et al. (2014), Imran et al. (2015), and Ohana and Meyer (2016) all asserted that high levels of justice foster an environment of affective commitment, while others have established a positive relationship between organizational justice and job satisfaction (Crow et al., 2012).

Despite numerous studies examining the relationships between the three constructs of organizational justice, job satisfaction, and affective commitment, none have explained the mechanism by which the concepts directly or indirectly affect one another. This study, therefore, uniquely explains the mechanism through depicting job satisfaction as a mediating variable between organizational justice and affective commitment, rather than as an independent variable. Jernigan et al. (2002) actually consider this to be a more favorable approach. In fact, several studies have uncovered a direct causal relationship between job satisfaction and affective commitment (Jernigan et al., 2002).

The information revealed in this study serves both academics and practitioners by highlighting the incredible importance of organizational justice as the capital for cultivating sought-after attitudes and behaviors among employees. Indeed, as described earlier, the chain of relationships could be explained by social exchange theory as the greater the justice perceived by employees in the workplace - whether distributional, procedural, and/or 
interactional - the more satisfied they will be with their jobs and, consequently, the more affectively committed they will become toward the organization through heightened feelings of belonging and devotion (Ohana and Meyer, 2016).

Furthermore, this study applies the well-established concepts of organizational justice, job satisfaction, and affective commitment to a virtually untapped region: Jordan. In confirming the findings of similar studies in more developed Western countries, this study indicates that cultural context does not play a major role, and that justice is valued and leads to desirable workplace outcomes regardless of the context. Nevertheless, because one study is not sufficient to fill the current literature gap, caution should be taken before generalizing such results to all developing Eastern countries.

\subsection{Managerial Implications}

Achieving optimum employee productivity has long been the goal of businesses across all sectors. To achieve this, organizations must ensure that their employees are satisfied with their jobs and committed to the organization (Kofi et al., 2016). This is where the study achieves its goal of presenting organizational justice as the antecedent of desirable employee outcomes. It is, thus, crucial for management to realize the importance of organizational justice in shaping employees' attitudes and behaviors. In fact, the sooner organizations realize the benefits of implementing all dimensions of organizational justice, the faster they will see results. On the contrary, if aspects of justice are neglected and unfairness spreads in the workplace, an environment of dissatisfaction, bitterness, and acrimony will be stimulated, which could lead to catastrophic outcomes, such as loss in productivity, poor performance, and/or high turnover (Rae \& Subramaniam, 2008).

In addition to implementing justice, it is vital for practitioners to understand the role of job satisfaction as a mediating variable between organizational justice and affective commitment. Since job satisfaction incorporates both emotional and attitudinal aspects, management can deduce the importance of job satisfaction as a potential determinant of many workplace outcomes (Goh et al., 2012). At the same time, it can easily be influenced by an organization's actions, such as in respect of organizational justice (Saha \& Kumar, 2017).

\section{Limitations and Future Research}

Given that a single study on a developing country cannot produce generalizable findings, the authors call for further testing of models pertaining to how organizational justice affects job satisfaction and, in turn, affective commitment. The study examined one dimension of organizational commitment (affective commitment) and excluded the other two dimensions (normative and continuance commitment). It included all dimensions of organizational justice as a single construct rather than examining the roles of distributional, procedural, and interactional justice on job satisfaction and affective commitment. It is therefore recommended that this model be tested in other industries to see if the results are consistent. Finally, it would also be beneficial for future research to separately consider the effects of each organizational justice dimension by exploring their individual effects on workplace attitudes and behaviors. Moreover, it would be useful to investigate the mediating role of job satisfaction on the relationship between components of organizational justice and the three types of commitment constructs in a Middle Eastern context.

\section{Conclusion}

There is a positive, significant relationship between organizational justice and affective commitment. However, the study confirmed that the relationship is not as direct as previous studies have depicted. In fact, job satisfaction serves as a mediating variable between the two. This accords with the findings of studies conducted in developed Western countries, which could indicate that justice is cherished regardless of the cultural or national context. Nevertheless, more studies need to be conducted in developing Eastern countries in order to bridge the gap caused by lack of prior research in such regions (Hao et al., 2016). In addition, the study emphasizes the importance of organizational justice in sparking desired employee attitudes and behaviors; therefore, management should pay attention to implementing justice in all its forms - distributional, procedural, and interactional - in the workplace. This is fundamental in reaping positive work outcomes from employees (Kofi et al., 2016).

\section{References}

Abekah-Nkrumah, G., \& Atinga, R. A. (2013). Exploring the link between organizational justice and job satisfaction and performance in Ghanaian hospitals: Do demographic factors play a mediating role? International Journal of Workplace Health Management, 6(3), 189-204. https://doi.org/10.1108/ijwhm-042011-0011

Akanbi, P. A., \& Ofoegbu, O. E. (2013). Impact of perceived organizational justice on organizational commitment of a food and beverage firm in Nigeria. International Journal of Humanities and Social Science, 4(14), 207- 
218.

Aküzüm, C. (2014). The effect of organizational justice and organizational cynicism on the organizational commitment: An application in primary education institutions. Mevlana International Journal of Education (MIJE), 4(3), 48-68.

Allen, N. J., \& Meyer, J. P. (1990). The measurement and antecedents of affective, continuance and normative commitment to the organization. Journal of Occupational Psychology, 63(1), 1-18. https://doi.org/10.1111/j.2044-8325.1990.tb00506.x

Allen, N. J., \& Meyer, J. P. (1996). Affective, continuance, and normative commitment to the organization: An examination of construct validity. Journal of Vocational Behavior, 49(3), 252-276. https://doi.org/10.1006/jvbe.1996.0043

Al-Zu'bi, H. A. (2010). A study of relationship between organizational justice and job satisfaction. International Journal of Business and Management, 5(12), 102-109. https://doi.org/10.5539/ijbm.v5n12p102

Anderson, J. C., \& Gerbing, D. W. (1988). Structural equation modeling in practice: A review and recommended two-step approach. Psychological Bulletin, 103(2), 411-423. https://doi.org/10.1037//0033-2909.103.3.411

Barakat, S. R., Isabella, G., Boaventura, J. M. G., \& Mazzon, J. A. (2016). The influence of corporate social responsibility on employee satisfaction. Management Decision, 54(9), 2325-2339. https://doi.org/10.1108/MD-05-2016-0308

Baron, R. M., \& Kenny, D. A. (1986). The moderator-mediator variable distinction in social psychological research: Conceptual, strategic, and statistical considerations. Journal of Personality and Social Psychology, 51(6), 1173-1182. https://doi.org/10.1037//0022-3514.51.6.1173

Bies, R. J. (2001). Interactional (in) justice: The sacred and the profane. In J. Greenberg, \& R. Cropanzano (Eds.), Advances in organizational justice (pp. 89-118). Stanford, CA: Stanford University Press.

Bies, R. J., \& Moag, J. S. (1986). Interactional justice: Communication criterion of fairness. In R. J. Lewicki, B. H. Sheppard, \& M. H. Bazerman (Eds.), Research on negotiation in organization (pp. 43-55). Greenwich, CT: JAI Press.

Bollen, K. A. (1989). Structural equations with latent variables. New York, NY: John Wiley \& Sons, Inc https://doi.org/10.1002/9781118619179

Chênevert, D., Jourdain, G., Cole, N., \& Banville, B. (2013). The role of organizational justice, burnout and commitment in the understanding of absenteeism in the Canadian healthcare sector. Journal of Health Organization and Management, 27(3), 350-367. https://doi.org/10.1108/jhom-06-2012-0116

Cheung, M. F. Y. (2013). The mediating role of perceived organizational support in the effects of interpersonal and informational justice on organizational citizenship behaviors. Leadership \& Organization Development Journal, 34(6), 551-572. https://doi.org/10.1108/LODJ-11-2011-0114

Choi, K. B., Moon, H. K., Ko, W., \& Kim, K. M. (2014). A cross-sectional study of the relationships between organizational justices and OCB. Leadership \& Organization Development Journal, 35(6), 530-554. https://doi.org/10.1108/lodj-08-2012-0103

Chou, T. Y., Seng-cho, T. C., Jiang, J. J., \& Klein, G. (2013). The organizational citizenship behavior of IS personnel: Does organizational justice matter? Information \& Management, 50(2), 105-111. https://doi.org/10.1016/j.im.2013.02.002

Colquitt, J. A., Conlon, D. E., Wesson, M. J., Porter, C. O. L. H., \& Ng, K. Y. (2001). Justice at the millennium: A meta-analytic review of 25 years of organizational justice research. Journal of Applied Psychology, 86(3), 425-445. https://doi.org/10.1037/0021-9010.86.3.425

Colquitt, J. A., Scott, B. A., Rodell, J. B., Long, D. M., Zapata, C. P., Conlon, D. E., \& Wesson, M. J. (2013). Justice at the millennium, a decade later: A meta-analytic test of social exchange and affect-based perspectives. Journal of Applied Psychology, 98(2), 199. https://doi.org/10.1037/a0031757

Crow, M. S., Lee, C., \& Joo, J. (2012). Organizational justice and organizational commitment among South Korean police officers. Policing: An International Journal of Police Strategies \& Management, 35(2), 402-423. https://doi.org/10.1108/13639511211230156

Dahiyat, S. E. (2015). An integrated model of knowledge acquisition and innovation: examining the mediation effects of knowledge integration and knowledge application. International Journal of Learning and 
Change, 8(2), 101-135. https://doi.org/10.1504/ijlc.2015.074064

Eisenberger, R., Huntington, R., Hutchison, S., \& Sowa, D. (1986). Perceived organizational support. Journal of Applied Psychology, 71(3), 500-507. https://doi.org/10.1037//0021-9010.71.3.500

Elamin, A. M. (2012). Perceived organizational justice and work-related attitudes: A study of Saudi employees. World Journal of Entrepreneurship, Management and Sustainable Development, 8(1), 71-88. https://doi.org/10.1108/20425961211221633

Esfahani, A. N., Ghasemi, A. R., \& Tabrizi, A. T. (2014). The relationship between management credibility and affective commitment in consultant engineering firms: Evidence from Iranian organizations. Social and Behavioral Sciences, 143, 947-952. https://doi.org/10.1016/j.sbspro.2014.07.532

Folger, R., \& Cropanzano, R. (1998). Organizational justice and human resource management, Beverly Hills, CA: Sage.

Fornell, C., \& Larcker, D. F. (1981). Structural equation models with unobservable variables and measurement error. Journal of Marketing Research, 18(1), 39-50. https://doi.org/10.1177/002224378101800104

Giri, V. N., \& Kumar, S. P. (2013). Assessing the impact of participation in decision making on organizational citizenship behaviour: The mediating role of organizational commitment. In D. Chatterjee, M. Dhal, \& S. P. Pati (Eds.), High-tech people, high-tech HR. Are we missing the humane touch? (pp. 41-46). New Delhi: Bloomsbury.

Goh, S. C., Elliott, C., \& Quon, T. K. (2012). The relationship between learning capability and organizational performance. The Learning Organization, 19(2), 92-108. https://doi.org/10.1108/09696471211201461

Greenberg, J. (1987). A taxonomy of organizational justice theories. Academy of Management Review, 12(1), 922. https://doi.org/10.2307/257990

Greenberg, J. (1990a). Organizational justice: yesterday, today, and tomorrow. Journal of Management, 16(2), 399-432. https://doi.org/10.1177/014920639001600208

Greenberg, J. (1990b). Looking fair vs. being fair: managing impressions of organizational justice. In L. L. Cummings, \& B. M. Staw (Eds), Research in organizational behavior (pp. 111-157). Greenwich, CT: JAI Press.

Gumus, M., Hamarat, B., Colak, E., \& Duran, E. (2012). Organizational and occupational identification: Relations to teacher satisfaction and intention to early retirement. Career Development International, 17(4), 300-313. https://doi.org/10.1108/13620431211255806

Hair, J., Black, W., Babin, B., \& Anderson, R. (2010). Multivariate data analysis. Upper Saddle River, NJ: Prentice Hall, Inc.

Halepota, J. A., \& Shah, N. (2011). An empirical investigation of organisational antecedents on employee job satisfaction in a developing country. Transforming Government: People, Process and Policy, 5(3), 280-294. https://doi.org/10.1108/17506161111155414

Hao, Y., Hao, J., \& Wang, X. (2016). The relationship between organizational justice and job satisfaction: Evidence from China. Journal of Chinese Human Resource Management, 7(2), 115-128. https://doi.org/10.1108/jchrm07-2016-0012

Hayes, A. (2009). Beyond Baron and Kenny: Statistical mediation analysis in the new millennium. Communication Monographs, 76(4), 408-420. https://doi.org/10.1080/03637750903310360

Hayes, A. F. (2013). Introduction to mediation, moderation, and conditional process analysis. New York, NY: The Guilford Press.

He, H., \& Brown, A. D. (2013). Organizational identity and organizational identification: A review of the literature and suggestions for future research. Group \& Organization Management, 38(1), 3-35. https://doi.org/10.1177/1059601112473815

Hu, L. \& Bentler, P. M. (1999). Cutoff criteria for fit indices in covariance structure analysis: Conventional criteria $\begin{array}{llllll}\text { versus new alternatives. Structural Equation } & \text { Modeling, 6(1), }\end{array}$ https://doi.org/10.1080/10705519909540118

Imran, R., Majeed, M., \& Ayub, A. (2015). Impact of organizational justice, job security and job satisfaction on organizational productivity. Journal of Economics, Business and Management, 3(9), 840-845. https://doi.org/10.7763/joebm.2015.v3.295 
Jernigan, I. E., Beggs, J. M., \& Kohut, G.F. (2002). Dimensions of work satisfaction as predictors of commitment type. Journal of Managerial Psychology, 17(7), 564-579. https://doi.org/10.1108/02683940210444030

Kofi, H., Asiamah, N., \& Mireku, K. (2016). The effect of organizational justice delivery on organizational commitment: Controlling for key confounding variables. Journal of Global Responsibility, 7(2), 1-14. https://doi.org/10.1108/jgr-06-2016-0015

Lam, L.W., Loi, R., \& Leong, C. (2013). Reliance and disclosure: How supervisory justice affects trust in supervisor and extra-role performance. Asia Pacific Journal of Management, 30(1), 231-249. https://doi.org/10.1007/s10490-011-9249-5

LaMastro, V. (2008). Commitment and perceived organizational support. National Forum, 19(1), 3-04.

Lambert, E. G. (2003). The impact of organizational justice on correctional staff. Journal of Criminal Justice, 31(2), 155-168. https://doi.org/10.1016/s0047-2352(02)00222-2

Latham, G., \& Pinder, C. (2005). Work motivation theory and research at the dawn of the twenty-first century. Annual Review of Psychology, 56, 485-516. https://doi.org/10.1146/annurev.psych.55.090902.142105

Lee, J. (2002). Influence of distributive justice and procedural justice on organizational effectiveness: An examination of incentives for government employees (Unpublished doctoral dissertation). Sejong University, Seoul, South Korea.

Liao, S. H., Hu, D. C., \& Chung, H. Y. (2009). The relationship between leader-member relations, job satisfaction and organizational commitment in international tourist hotels in Taiwan. The International Journal of Human Resource Management, 20(8), 1810-1826. https://doi.org/10.1080/09585190903087222

Locke, E. A. (1976). The nature and causes of job satisfaction. In M. D. Dunnette (Ed.), Handbook of industrial and organizational psychology (pp. 1297-1349). Chicago, IL: Rand McNally.

Lok, P., \& Crawford, J. (2001). Antecedents of organizational commitment and the mediating role of job satisfaction. Journal of Managerial Psychology, 16(8), 594-613. https://doi.org/10.1108/eum0000000006302

López-Cabarcos M. A., Pinho, A. I. M., \& Rodríguez, P. (2016). Combined antecedents of prison employees' affective commitment using fsQCA. Journal of Business Research, 69(11) 5534-5539. https://doi.org/10.1016/j.jbusres.2016.04.167

MacKinnon, D. (2008). Introduction to statistical mediation analysis. New York, NY: Lawrence Erlbaum. https://doi.org/10.4324/9780203809556

Mallinckrodt, B., Abraham, T., Wei, M., \& Russell, D. (2006). Advance in testing statistical significance of mediation effects. Journal of Counseling Psychology, 53(3), 372-378. https://doi.org/10.1037/00220167.53.3.372

Marzucco, L., Marique, G., Stinglhamber, F., De Roeck, K., \& Hansez, I. (2014). Justice and employee attitudes during organizational change: The mediating role of overall justice. Revue Européenne de Psychologie Appliquéel European Review of Applied Psychology, 64(6), 289-298. https://doi.org/10.1016/j.erap.2014.08.004

Mensah, H. K., Akuoko, K. O., \& Ellis, F. (2016). An empirical assessment of health workers' organisational commitment in Ghana: A comparative analysis. International Journal of Business and Management, 11(3), 183-192. https://doi.org/10.5539/ijbm.v11n3p183

Meyer, J. P., Stanley, D. J., Herscovitch, L., \& Topolnytsky, L. (2002). Affective, continuance, and normative commitment to the organization: A meta-analysis of antecedents, correlates, and consequences. Journal of Vocational Behaviour, 61(2), 20-52. https://doi.org/10.1006/jvbe.2001.1842

Meyer, J.P., \& Allen, N.J. (1991). A three-component conceptualization of organizational commitment. Human Resource Management Review, 1(1), 61-98. https://doi.org/10.1016/1053-4822(91)90011-z

Mohammad, J., Quoquab, F., Quoquab, F., Makhbul, Z. M., Makhbul, Z. M., ... \& Ramayah, T. (2016). Bridging the gap between justice and citizenship behavior in Asian culture. Cross Cultural \& Strategic Management, 23(4), 633-656. https://doi.org/10.1108/ccsm-08-2015-0097

Moon, T., Hur, W., Ko, S., Kim, J., \& Yoon, S. (2014). Bridging corporate social responsibility and compassion at work. Career Development International, 19(1), 49-72. https://doi.org/10.1108/cdi-05-2013-0060

Morin, A. J., Vandenberghe, C., Boudrias, J. S., Madore, I., Morizot, J., \& Tremblay, M. (2011). Affective commitment and citizenship behaviors across multiple foci. Journal of Managerial Psychology, 26(8), 716- 
738. https://doi.org/10.1108/02683941111181798

Mowday, R., Porter, L., \& Steers, R. (1982). Employee organization linkages: The psychology of commitment, absenteeism, and turnover. New York, NY: Academic Press.

Niehoff, B. P., \& Moorman, R. H. (1993). Justice as a mediator of the relationship between methods of monitoring and organizational citizenship behavior. Academy of Management Journal, 36(3), 527-556. https://doi.org/10.5465/256591

Ohana, M. (2014). A multilevel study of the relationship between organizational justice and affective commitment: The moderating role of organizational size and tenure. Personnel Review, 43(5), 654-671. https://doi.org/10.1108/pr-05-2013-0073।

Ohana, M., \& Meyer, M. (2016). Distributive justice and affective commitment in nonprofit organizations: Which referent matters? Employee Relations: The International Journal, 38(6), 1-28. https://doi.org/10.1108/er-102015-0197

Park, Y., Song, J. H., \& Lim, D. H. (2016). Organizational justice and work engagement: the mediating effect of self-leadership. Leadership \& Organization Development Journal, 37(6), 711-729. https://doi.org/10.1108/lodj-09-2014-0192

Rae, K., \& Subramaniam, N. (2008). Quality of internal control procedures: antecedents and moderating effect on organizational justice and employee fraud. Managerial Auditing Journal, 23(2), 104-124. https://doi.org/10.1108/02686900810839820

Rai, S. (2015). Organizational justice and employee mental health's moderating roles in organizational identification. South Asian Journal of Global Business Research, 4(1), 68-84. https://doi.org/10.1108/sajgbr01-2014-0006

Randall, M. L., Cropanzano, R., Bormann, C.A., \& Birjulin, A. (1999). Organizational politics and organizational support as predictors of work attitudes, job performance, and organizational citizenship behavior. Journal of Organizational Behavior, 20(2), 159-174. https://doi.org/10.1002/(sici)1099-1379(199903)20:2<159::aidjob881>3.0.co;2-7

Rego, A., \& Cunha, M.P. (2008). Workplace spirituality and organizational commitment: An empirical study. Journal of Organizational Change Management, 21(1), 53-75. https://doi.org/10.1108/09534810810847039

Riggle, R. J., Edmondson, D. R., \& Hansen, J. D. (2009). A meta-analysis of the relationship between perceived organizational support and job outcomes: 20 years of research. Journal of Business Research, 62(10), $1027-$ 1030. https://doi.org/10.1016/j.jbusres.2008.05.003

Saha, S., \& Kumar, P. (2017). Influence of participation in decision making on job satisfaction, group learning, and group commitment: Empirical study of public sector undertakings in India. Asian Academy of Management Journal, 22(1), 79-101. https://doi.org/10.21315/aamj2017.22.1.4

Shrout, P., \& Bolger, N. (2002). Mediation in experimental and nonexperimental studies: new procedures and recommendations. Psychological Methods, 7(4), 422-445. https://doi.org/10.1037//1082-989x.7.4.422

Skarlicki, D. P., \& Kulik, C. T. (2004). Third-party reactions to employee (mis) treatment: A justice perspective. Research in Organizational Behavior, 26, 183-229. https://doi.org/10.1016/s0191-3085(04)26005-1

Suliman, A., \& Al Kathairi, M. (2012). Organizational justice, commitment and performance in developing countries: The case of the UAE. Employee Relations, 35(1), 98-115. https://doi.org/10.1108/01425451311279438

Wang, X., Liao, J., Xia, D., \& Chang, T. (2010). The impact of organizational justice on work performance. International Journal of Manpower, 31(6), 660-677. https://doi.org/10.1108/01437721011073364

Zainalipour, H., Fini, A. A. S., \& Mirkamali, S. M. (2010). A study of relationship between organizational justice and job satisfaction among teachers in Bandar Abbas middle school. Procedia-Social and Behavioral Science, 5,1986-1990. https://doi.org/10.1016/j.sbspro.2010.07.401

\section{Copyrights}

Copyright for this article is retained by the author(s), with first publication rights granted to the journal.

This is an open-access article distributed under the terms and conditions of the Creative Commons Attribution license (http://creativecommons.org/licenses/by/4.0/). 